\title{
IMPLEMENTASI TQM DALAM MENINGKATKAN MUTU PENDIDIKAN DI MTs. ISTIQOMAH TALAMAU KABUPATEN PASAMAN BARAT
}

\author{
Alwizra \\ Kepala MI Muhammadiyah Sei. Jernih-Talu \\ Korespondensi: Sei. Jernih Talu Kabupaten Pasaman Barat, Sumatera Barat \\ e-mail: alwiael326@gmail.com
}

2000

\begin{abstract}
This research discussed abaut the Implementation of TQM at MTs. Istiqomah Talamau in improving the quality of education. This research has purposes: to know the process of TQM implemantation in improving the quality of education, to know the characteristic of TQM that has been implemented, to know changes that was occured in the quality of a education after the implementation of TQM, and to know trouble that was occured in implementation of TQM to improve the quality of education at MTs Istiqomah Talamau. This research used qualitatif research approach, and the type of research that was used was etnography. This research has been done at MTs Istoqomah Talamau Kabupaten Pasaman Barat. The sources of data in this research was: the source of data directly from MTs Istiqomah Talamau, the source of data was not direct that was the data which was transferred the data to data collector. Data collection technique used observation, interview, and document collection. Data analisis technique used Miles and Huberman data model. The result of this resech found out: the Implementation of TQM used four steps, these are: Quality planning management, Program implementation management, Management control, Activity evaluation management. Then, the Implementation of of TQM's characteristic that was applied at MTs. Istiqomah Talamau was: Costomer satisfication, Improving product quality, Respecting to every people, Building a team work, and implementating the improvements countinously.
\end{abstract}

Keywords: Total Quality Management, quality, education, MTs. Istiqomah Talamau

\section{PENDAHULUAN}

Kemajuan pesat dalam bidang ilmu pengetahuan, teknologi dan seni mendorong masyarakat muslim untuk mewujudkan cita-citanya melalui proses pendidikan Islam yang bermutu. Timbulnya kebutuhan tersebut sejalan dengan adanya perubahan zaman disegala aspek kehidupan manusia yang kian hari semakin bertambah kompleks.

Perubahan zaman yang kompleks ini tidak akan dapat diatasi dengan baik, jika sumber daya manusiayang berperan di dalamnya tidak bermutu tinggi. Dengan ketersediaan sumber daya manusia yang bermutu tinggi akan dapat melahirkan sistim pengelolaan pendidikan yang baik

Implementasi TQM dalam Meningkatkan Mutu Pendidikan di MTs Istiqomah Talamau... $\quad 39$ 
guna mencapai mutu pendidikan yang baik pula.

Madrasah sebagai lembaga pendidikan Islam formal yang terintegrasi dalam sistem pendidikan nasional di Indonesia memerlukan manajemen mutu. Peningkatan jumlah madrasah yang umumnya berstatus swasta perlu diimbangi dengan peningkatan mutunya secara terencana dan berkelanjutan.

Himpunan Perundangan-undangan Republik Indonesia Nomor 20 Tahun 2003 tentang Sistim Pendidikan Nasional (UUSPN) BAB III Pasal 4 ayat 6 (2012:4), mengamanatkan agar pendidikan diselenggarakan dengan memberdayakan semua komponen masyarakat melalui peran serta dalam penyelenggaraan dan pengendalian mutu layanan pendidikan.

Konsep ini menuntut kepada semua pihak dalam suatu institusi untuk mengelola mutu secara strategis. Dengan kata lain, bagaimana suatu institusi, baik perusahaan maupun institusi pendidikan mampu melakukan langkah-langkah strategis dalam mengendalikan mutu dan menjamin mutu produk atau lulusan lembaga pendidikan untuk memuaskan pelanggan pendidikan atau masyarakat.

Usaha dalam mencapai pendidikan yang bermutu Makbuloh (2014:20) berpendapat bahwa, implementasi sistem manajemen paling dominan dalam menentukan arah kebijakan pendidikan. Oleh karena itu, dalam upaya mempersiapkan sistim manajemen pendidikan yang bermutu berarti perlu berbicara tentang ilmu manajemen pendidikan secara baik.

Para tokoh dalam bidang pendidikan berbeda pandangan tentang teori manajemen mutu. Sebagaimana dikutip Makbuloh (2014: 3), ada beberapa teori yang berkembang dalam manajemen mutu, yang dijadikan sebagai rujukan sebagai upaya untuk meningkatkan dan menjamin mutu, diantaranya; quality control ( $(Q C)$, quality assurance (QA), total quality control (TQC), total quality management (TQM), dan school base management (SBM).Semua teori menempatkan quality (mutu) sebagai pusat pengawasan dan evaluasi.

Jika diklasifikasikan dalam bidangnya, dua teori yang terakhir menjadi isu yang populer dalam bidang pendidikan, yaitu TQM dan SBM. Karena TQM dan SBM memiliki bangunan teori yang relevan dengan karakteristik sekolah/madrasah sebagai layanan jasa. Namun dalam uraian penelitian ini, fokus kajian penulis adalah berkenaan dengan Total Quality Management atau disingkat dengan TQM.

Keterikatan antara implementasi TQM dan mutu pendidikan menarik perhatian beberapa sekolah/madrasah di Indonesia, dan menjadikan TQM sebagai langkah taktis strategis dalam meningkatkan mutu pendidikan. Salah satu lembaga pendidikan yang menjadikan TQM sebagai upaya dalam rangka peningkatan mutu pendidikan, adalah di lembaga pendidikan yang penulis jadikan sebagai lokasi penelitian, yaitu; MTs. Istiqomah Talamau di Kabupaten Pasaman Barat.

MTs. Istiqomah Talamau mengalami perubahan mutu setelah pelaksanaan TQM. Adapun sebelum pelaksanaan TQM, yaitu sebelum tahun ajaran 2012/2013, MTs. Istiqomah Talamau tidak begitu diminati oleh masyarakat di Kecamatan Talamau, hal 
ini ditandai dengan jumlah siswa MTs. Istiqomah Talamau lebih sedikit dibanding sekolah/madrasah tingkat SLTP lainnya yang ada di Kecamatan Talamau.

Namun setelah pelaksanaan TQM MTs. Istiqomah Talamau mengalami banyak perubahan yang bersifat positif, hal ini terlihat pada beberapa aspek, diantaranya: (1) prestasi madrasah meningkat, (2) jumlah penerimaan peserta didik bertambah, (3) dan lulusan MTs. Istiqomah Talamau diterima dibeberapa sekolah/madrasah bertstandar Nasional di Provinsi Sumatera Barat.

Fakta-fakta di atas, memberikan indikasi bahwa implementasi TQM telah memberikan perubahan mutu pendidikan di MTs. Istiqomah Talamau. Oleh karena itu, pada penelitian ini penulis bertujuan untuk mengetahui proses pelaksanaan TQM di MTs. Istiqomah Talamau.

\section{KAJIAN TEORITIS}

\section{Total Quality Management (TQM)}

Menurut Nasution (2005: 18), TQM merupakan suatu pendekatan dalam menjalankan usaha yang mencoba untuk memaksimalkan daya saing organisasi melalui perbaikan terus menerus atas produk, jasa, manusia, tenaga kerja, proses, dan lingkungan.

Pengertian lain dikemukakan oleh Santoso yang di kutip oleh Tjiptono dan Diana (1998: 35) yang mengatakan bahwa TQM merupakan sistem manajemen yang mengangkat kualitas sebagai strategi usaha dan berorientasi pada kepuasan pelanggan dengan melibatkan seluruh anggota organisasi. Disamping itu juga Fandy
Tjiptono dan Nastasia Diana (1998: 36), menyatakan pula bahwa Total Quality Management merupakan suatu pendekatan dalam menjalankan usaha yang mencoba untuk memaksimumkan daya saing organisasi melalui perbaikan terus menerus atas produk, jasa, manusia, proses dan lingkungannya.

Menurut Nawawi (2005:10), mengemukakan tentang karakteristik TQM sebagai berikut :

a. Fokus pada pelanggan, baik pelanggan internal maupun pelanggan eksternal.

b. Memiliki obsesi yang tinggi terhadap kualitas.

c. Menggunakan pendekatan ilmiah dalam pengambilan keputusan dan pemecahan masalah.

d. Memiliki komitmen jangka panjang

e. Membutuhkan kerjasama tim

f. Memperbaiki proses secara kesinambungan.

g. Menyelenggarakan pendidikan dan pelatihan.

h. Memberikan kebebasan yang terkendali

i. Adanya keterlibatan dan pemberdayaan karyawan.

Selanjutnya ditegaskan oleh Aminatul Zahroh dalam Journal Cendikia (2015: 82) menjelaskan bahwa pada prinsipnya TQM terus mengadakan perbaikan, oleh karena itu, untuk mensukseskan TQM dibutuhkan sebuah manajemen pengendalian mutuyang sempurna.

\section{Mutu Pendidikan}

Defenisi mutu menurut para ahli sebagai mana yang dikutip oleh Hadis dan Nurhayati. B (2014: 84) mendefenisikan 
mutu dalam perspektif produk yang dihasilkan oleh suatu perusahaan, sebagai berikut:

a. Menurut Juran (1993), mutu produk ialah kecocokan penggunaan produk (fitness for use) untuk memenuhi kebutuhan dan kepuasan pelanggan.

b. Menurut Crosby (1979) mutu ialah comformance to requirement, yaitu sesuai dengan yang disyaratkan atau. distandarkan. Suatu produk memiliki produk apabila sesuai dengan standar atau kriteria mutu yang telah ditentukan, standar mutu tersebut meliputi bahan baku, proses, produksi, dan produk jadi.

c. Menurut Deming (1982) mutu ialah kesesuaian dengan kebutuhan pasar atau konsumen. Perusahaan yang bermutu ialah perusahaan yang menguasai pangsa pasar karena hasil produksinya sesuai dengan kebutuhan konsumen.

d. Menurut Feigenbaum (1986) mutu adalah kepuasan pelanggan sepenuhnya (full customer satisfaction). Suatu produk dianggap bermutu apabila dapat memberikan kepuasan sepenuhnya kepada konsumen, yaitu sesuai dengan harapan konsumen atas produk yang diusahakan oleh perusahaan.

e. Garvi dan Davis (1994) menyatakan bahwa mutu adalah suatu kondidim dinamik yang berhubungan dengan produk, tenaga kerja, proses, dan tugas serta lingkungan yang memenuhi atau melebihi harapan pelanggan.

Menurut Abdulah Hadis dan Nurhayati. B (2014: 86) urgensi mutu dapat dilihat dalam dua perspektif, yaitu manajemen operasional dan pemasaran. Dari perspektif manajemen operasional, mutu produk merupakan salah satu kebijaksanaan penting dalam meningkatkan daya saing suatu produk yang harus memberi kepuasan kepada konsumen melebihi atau paling tidak sama dengan kualitas produk dari pesaing.

\section{METODE PENELITIAN}

Pendekatan penelitian yang digunakan adalah Kualitatif, yaitu penelitian yang dimaksudkan untuk menyimpulkan informasi mengenai status gejala yang ada, yaitu gejala menurut apa yang ada pada saat penelitian dilakukan. (Sugiyono, 2012: 1). Sementara jenis penelitian yang diguanakan adalah Etnografi. Tujuan penelitian Etnografi adalah mengidentifikasikan pekerjaan, masalah, dan kemungkinan yang bersifat rutin, yang berkembang pada aktivitas setting yang ada.

Sumber data dalam penelitian ini adalah kata-kata atau ucapan lisan dan prilaku atau sikap dari subyek (informan) yang berkaitan dengan implementasi TQM dalam meningkatkan mutu pendidikan, serta dokumen-dokumen yang berkaitan dengan impelementasi TQM. Tekhnik pengumpulan data yang penulis gunakan adalah purposive sampling, yaitu tekhnik pengambilan sumber data dengan pertimbangan tertentu.

Pengumpulan data dilapangan peneliti lakukan dengan beberapa cara yaitu observasi, wawancara dan analisis dokumen. Analisis data dalam penelitian ini dilakukan secara kualitatif model Miles dan 
Huberman, yaitu data yang diperoleh disusun secara sistematis kemudian dianalisis untuk mencapai kejelasan masalah yang dibahas, apa yang dinyatakan responden secara tertulis, lisan dan juga prilakunya yang nyata, diteliti dan dipelajari sebagai sesuatu yang utuh.

\section{HASIL DAN PEMBAHASAN}

\section{Hasil Penelitian}

\section{Implementasi TQM di MTs. Istiqomah Talamau}

a. Manajemen Perencanaan Mutu

Manajemen perencanaan mutu pendidikan di MTs. Istiqomah Talamau yaitu pihak madrasah melibatkan stakeholder atau pemangku kepentingan pendidikan pada rapat penggalian gagasan dalam rangka menyusun program-program madrasah. Sehingga program yang disusun dan dilaksanakan oleh madrasah disesuaikan dengan kebutuhan pelanggan pendidikan. Hal ini dilakukan sebagai upaya untuk meningkatkan kepuasan pelanggan pendidikan yaitu orang tua/masyarakat setempat.

b. Manajemen Pelaksanaan Kegiatan Implementasi TQM di MTs. Istiqomah Talamau pada tahap pelaksanaan program yaitu madrasah membangun tim kerja/team work. Upaya membangun team work ini adalah dengan melakukan pelelangan program kepada majelis guru/karyawan madrasah. Personil diberikan kebebasan memilih program yang telah disusun oleh madrasah untuk dilaksanakan. c. Manajemen Kontrol

Manajemen kontrol TQM di MTs. Istiqomah Talamau dalam meningkatkan mutu pendidikan adalah dengan membuat papan prestasi kinerja. Setiap guru/karyawan diberikan target kerja berdasarkan tugas satuan kerja masingmasing, selanjutnya kepada seluruh guru/karyawan diberikan penilaian atas kinerjanya, penilaian tersebut ditulis pada papan prestasi. Diakhir semester kepala sekolah membuat perengkingan kinerja, dan memberikan penghargaan kepada personil yang berprestasi.

d. Manajemen Evaluasi

Manajemen evaluasi TQM dengan melibatkan berbagai unsur. Adapun pihak-pihak yang dilibatkan diantaranya unsur pimpinan, majelis guru/karyawan, pihak yayasan, komite madrasah, orang tua/wali murid dan juga tokoh pendidik/masyarakat setempat. Manajemen evaluasi TQM dengan melibatkan banyak pihak dimaksudkan agar ada perbaikan secara menyeluruh dari seluruh anggota rapat. Seluruh anggota rapat diberikan kesempatan untuk memberikan penilaian, saran dan pendapat untuk perbaikan mutu pendidikan.

\section{Karakteristik Implementasi TQM di MTs. Istiqomah Talamau}

a. Berorientasi Kepada Kepuasan Pelanggan

Kepuasan pelanggan pendidikan yaitu siswa dan orang tua/wali murid/masyarakat. Hal tersebut terlihat 
dari upaya-upaya yang dilakukan oleh pihak madrasah.

b. Meningkatkan Kualitas Produk

Adapun upaya yang dilakukan dalam meningkatkan mutu produk adalah pertama; membangun komitmen bersama dengan seluruh pemangku kepentingan. Kedua; melakukan pengklasifikasian lokal berdasarkan tingkat kemampuan siswa dan memberikan layanan sesuai dengan tingkat kebutuhan lokal yang telah dibagi.

c. Respek Terhadap Setiap Orang

Dalam meningkatkan mutu pendidikan MTs. Istiqomah Talamau selalu melibatkan seluruh stakeholder madrasah. Menurut responden untuk mencapai pendidikan yang bermutu perlu adanya kinerja yang maksimal dari personil madrasah.

d. Membangun Team Work

Adapun upaya-upaya yang dilakukan oleh MTs. Istiqomah Talamau dalam membangun team work adalah; pertama; keikut sertaan banyak pihak dalam merencanakan program kegiatan madrasah. Kedua; penempatan personil sesuai dengan bidang keahlian. Ketiga; pekerjaan yang dilakukan oleh ahlinya. Keempat; melaksanakan briefing setiap ada permasalahan.

e. Melakukan Perbaikan Secara Kontiniu Perbaikan secara kontiniu yang dilaksanakan oleh madrasah adalah bertujuan untuk melakukan pembenahan dan penyesuai terhadap hal-hal baru. Perbaikan secara kontiniu dilakukan secara bersama, melibatkan seluruh majelis guru/karyawan, komite madrasah, dan orang tua/wali murid. Perbaikan secara kontiniu ini adalah menyakut tentang pengelolaan/ manajemen madrasah dalam melaksanakan program kegiatan.

\section{Pembahasan}

\section{Implementasi TQM di MTs. Istiqomah}

\section{Talamau}

a. Manajemen Perencanaan Mutu

Konsep TQM melibatkan seluruh anggota organisasi serta mengutamakan kepuasan pelanggan sebagai mana yang dilaksanakan MTs. Istiqomah Talamau. Pada dasarnya senada dengan teori TQM yang disampaikan oleh Santoso sebagaimana dikutip Tjiptono dan Diana (1998: 35) yang mengatakan bahwa TQM merupakan sistem manajemen yang mengangkat kualitas sebagai strategi usaha dan berorientasi pada kepuasan pelanggan dengan melibatkan seluruh anggota organisasi.

Manajemen perencanaan mutu dengan cara melibatkan stakeholder madrasah, telah dirasakan manfaatnya oleh MTs. Istiqomah Talamau. Upaya madrasah dalam meningkatkan kepuasan pelanggan, dapat dicapai dengan cara melibatkan banyak pihak. Begitu juga dengan kualitas produk/lulusan yang dihasilkan oleh MTs. Istiqomah Talamau, dapat diraih dengan perencanaan mutu yang matang. Perencanaan mutu yang matang, lahir dari sebuah kesepakatan bersama melalui keterlibatan seluruh stakeholder madrasah dalam merencanakan program kegiatan madrasah. 
b. Manajemen Pelaksanaan Kegiatan

Pelaksanaan kegiatan dilaksanakan dengan melakukan lelang kerja kepada seluruh personil. Selanjutnya Rasmi (2014: 58), menguraikan unsur penting yang perlu diperhatikan dalam memahami hakekat mutu terpadu dalam pendidikan (Total Quality In Education), yaitu; pembagian tanggung jawab dan pemberdayaan karyawan sekolah yaitu pemberdayaan karyawan sangat penting dalam perbaikan mutu suatu sekolah.

Setiap lembaga pendidikan perlu membangun team work sebelum melaksana- kan program kegiatan. Program kegiatan akan dapat dilaksanakan dengan baik, apa bila dikerjakan oleh tebuah tim yang solid. Sementara untuk membangun tim yang solid perlu adanya komitmen bersama. Maka, lembaga pendidikan yang berkualitas dan bermutu akan dapat dicapai oleh team work yang memiliki komitmen bersama.

c. Manajemen Kontrol

Manajemen kontrol yang dilakukan oleh MTs. Istiqomah Talamau adalah dengan membuat data prestasi. Menurut Hensler dan Brunell (dalam Scheuing dan Christopher, 1993) sebagaimana dikutip oleh Prihantoro (2012: 71), bahwa perusahaan kelas dunia berorientasi pada fakta. Maksudnya bahwa setiap keputusan selalu didasarkan pada data, bukan sekedar pada perasaan (feeling).

Manajemen kontrol sebagaimana yang dilaksanakan oleh MTs. Istiqomah Talamau dalam implementasi TQM guna meningkatkan mutu pendidikan, memberikan efek positif terhadap setiap personil dalam meningkatkan kinerjanya tanpa harus diperintah.

Perbaikan manajemen membutuhkan data-data atau fakta ilmiah yang dapat diukur dan dipertanggung jawabkan. Oleh karena itu, pelaksanaan kontrol yang dilakukan oleh MTs. Istiqomah Talamau adalah dengan membuat Grafik Prestasi atau Prestasi Kerja yang dipajang secara terbuka dan dapat diketahui umum.

d. Manajemen Evaluasi

Pelaksanaan manajemen evaluasi TQM dilaksanakan secara kontiniu, serta melibatkan stakeholder madrasah. Selanjutnya, Rasmi (2014: 58) menjelaskan bahwa perbaikan terus menerus yaitu melakukan suatu tindakan pengejaran atas mutu, prosesnya harus secara terus menerus diperbaiki dengan diubah, ditambah, dikembangkan dan dimurnikan.

Pelaksanaan evaluasi kegiatan perlu dimanajemen dengan sebaikbaiknya, sehingga evaluasi yang dilakukan dapat berdampak positif terhadap perkembangan serta peningkatan mutu. Oleh karena itu, prinsip evaluasi yang terpenting adalah kontiniu. Evaluasi yang dilaksanakan secara terus menerus oleh lembaga pendidikan akan dapat berdampak pada peningkatan mutu pendidikan itu sendiri. 
Karakteristik Implementasi TQM di MTs. Is.tiqomah Talamau

a. Berorientasi Kepada Kepuasan Pelanggan

Karakteristik Implementasi TQM pertama yang dilakukan oleh MTs. Istiqomah Talamau adalah mengutamakan kepuasan pelanggan pendidikan yaitu siswa dan orang tua/wali murid/masyarakat. Rasmi (2014: 58), menguraikan unsur penting yang perlu diperhatikan dalam memahami hakekat mutu terpadu dalam pendidikan (Total Quality In Education), yaitu; pencapaian kepuasan harapan pelanggan pendidikan.

Mengutamakan kepuasan pelanggan adalah merupakan salah satu karakteristik TQM sebagaimana dijelaskan oleh banyak ahli. Kepuasan pelanggan terhadap produk yang dihasilkan dipandang sebagai hasil dari tindakan manajemen. Lembaga pendidikan dinilai berhasil dalam membuat sebuah produk, apa bila produk yang dihasilkan dibutuhkan dan dapat memuaskan pelanggan pendidikan.

b. Meningkatkan Kualitas Produk

Kualitas mutu produk dimaksudkan untuk meningkatkan minat masyarakat terhadap madrasah. Begitu juga dengan mutu pendidikan, mutu pendidikan dapat menentukan minat masyarakat terhadap lembaga pendidikan. Dapat dipahami bahwa pendidikan yang bermutu adalah pendidikan yang diminati, pendidikan yang bermutu adalah pendidikan yang memiliki produk yang berkualitas.

Untuk mencapai kualitas mutu pendidikan, ditambahkan penjelasan oleh Syukron (2017: 60) memberikan keterangan bahwa komitmen untuk berubah kearah mutu yang lebih baik harus dipahami oleh semua level manajemen dan harus didasari oleh kehendak mau berubah.

Komitmen mutu tersebut betulbetul dapat dipahami secara mendalam oleh setiap pemangku kepentingan pendidikan. Dengan demikian, peningkatan kualitas mutu produk akan dapat diwujudkan secara berkesinambungan.

c. Respek Terhadap Setiap Orang

MTs. Istiqomah Talamau selalu melibatkan seluruh stakeholder madrasah. Menurut Hensler dan Brunell (dalam Scheuing dan Christopher, 1993) sebagaimana dikutip oleh Prihantoro (2012: 71), dalam perusahaan yang kualitasnya kelas dunia, setiap karyawan dipandang sebagai individu yang memiliki talenta dan kreativitas sendiri yang unik. Dengan demikian karyawan merupakan sumber daya organisasi yang paling bernilai. Oleh karena itu setiap orang dalam organisasi diperlakukan dengan baik dan diberi kesempatan untuk terlibat dan berpartisipasi dalam tim pengambilan keputusan.

TQM memberdayakan setiap potensi dan membuatnya fokus pada satu titik pencapaian, yaitu peningkatan mutu. TQM sangat menghargai setiap 
keberagaman, dan memanfaatkan setiap potensi yang tersedia, sehingga setiap personil merasa dilibatkan dan terlibat dalam proses peningkatan mutu pendidikan.

d. Membangun Team Work

MTs. Istiqomah Talamau melakukan upaya untuk membangun team work dalam mengimpelementasikan TQM. Adapun upaya-upaya yang dilakukan oleh MTs. Istiqomah Talamau dalam membangun team work adalah; pertama; keikut sertaan banyak pihak dalam merencanakan program kegiatan madrasah. Kedua; penempatan personil sesuai dengan bidang keahlian. Ketiga; pekerjaan yang dilakukan oleh ahlinya, memiliki kemungkinan besar berhasil dalam pelaksanaannya. Keempat; melaksanakan briefing setiap ada permasalahan, hal ini sangat membantu manajerial madrasah dalam menjaga keutuhan dan kebersamaan tim kerja.

Karakteristik TQM membutuhkan kerja sama tim atau team work telah dijelaskan oleh beberapa ahli diantaranya; Goetsch dan Davis (1994) sebagaimana dikutip oleh Prihantoro (2012: 71), bahwa TQM memiliki karakteristik membangun team work. Team work dalam TQM adalah merupakan kunci kesuksesan suatu manajemen, seluruh perencanaan program hanya akan dapat dilaksanakan dengan baik apa bila suatu lembaga mampu membangun team work.

e. Melakukan Perbaikan Secara Kontiniu
Perbaikan secara kontiniu yang dilaksanakan oleh madrasah adalah bertujuan untuk melakukan pembenahan dan penyesuai terhadap hal-hal baru. Beberapa teori yang menjelaskan tentang pentingnya meningkatkan kualitas produk yang menjadi salah satu karakteristik TQM sebagai mana dijelaskan oleh Rasmi (2014: 58), bahwa peningkatan mutu dapat dicapai dengan melakukan perbaikan secara terus menerus, sehingga produk dan jasa yang dihasilkan dapat dimanfaatkan dan memberikan kepuasan tersendiri pada diri konsumen.

Perbaikan secara kontiniu ini adalah menyakut tentang pengelolaan/ manajemen madrasah dalam melaksanakan program kegiatan. Keterlibatan stakeholder adalah dalam upaya perbaikan secara terus-menerus yaitu perbaikan jangka panjang. Keterlibatan stakeholder madrasah akan membawa inovasi program untuk meningkatkan mutu pendidikan.

\section{Perubahan MutuPendidikan Pasca Implementasi TQM di MTs. Istiqomah Talamau}

Uraian yang disampaikan oleh responden di atas dapat disimpulkan bahwa implementasi TQM telah mengatarkan MTs. Istiqomah Talamau menjadi lembaga pendidikan yang bermutu dan mampu bersaing dalam kualitas maupun dalam kuantitas di tingkat Kabupaten, Provinsi 
dan Nasional bersama MTs. negeri ataupun swasta.

Kesuksesan MTs. Istiqomah Talamau dapat dilihat dari beberapa fakta dilapangan, seperti; jumlah siswa meningkat drastis hingga mencapai 267 lebih. Jumlah tersebut adalah jumlah siswa terbanyak SLTP negeri swasta yang ada di Talamau.

Prestasi madrasah dapat dicapai dengan baik pada ajang lomba/kompetesi antar SLTP yang ada di Kecamatan, Kabupaten dan Provinsi. Madrasah dapat bersaing pada UN semenjak 2015 s.d 2017 dan memperoleh peringkat 3 besar dari 54 MTs negeri swasta yang ada di Kab. Pasaman Barat. Lulusan madrasah dapat diterima diberbagai SLTA berstandar Nasional yang ada di Prov. Sumatera Barat.

Fakta-fakta di atas memberikan indikasi bahwa Implementasi TQM telah berhasil mengantarkan MTs. Istiqomah Talamau kepada perubahan mutu pendidikan. Pencapaian prestasi serta beberapa fakta baru MTs. Istiqomah Talamau baru terjadi setelah tahun 2013, yaitu setelah MTs. Istiqomah Talamau mengimplementasikan TQM. Implementasi TQM adalah solusi nyata bagi MTs. Istiqomah Talamau dalam upaya meningkatkan mutu pendidikan.

\section{PENUTUP}

\section{Simpulan}

Implementasi TQM di MTs. Istiqomah Talamau dilaksanakan dengan empat tahapan, yaitu: (1) manajemen perencanaan dengan cara melibatkan stakeholder madrasah, (2) manajemen pelaksanaan dengan melakukan lelang beban kerja, (3) manajemen kontrol dilaksanakan dengan membuat papan prestasi personil, (4) dan manajemen evaluasi dilakukan dengan cara melaksanakan secara kontiniu.

TQM yang dilaksanakan MTs. Istiqomah Talamau dengan karakteristik, antara lain: (1) mengutamakan kepuasan pelanggan, (2) meningkatkan kualitas produk, (3) respek terhadap setiap orang, (4) membangun tim kerja berdasarkan bidang keahlian, (5) melakukan perbaikan secara kontiniu dilakukan secara bersama, dan terbuka bertujuan untuk perbaikan jangka panang.

\section{Saran}

Adapun saran-saran peneliti tentang implementasi TQM di MTs. Istiqomah Talamah, adalah sebagai berikut:

a. MTs. Istiqomah Talamau perlu melakukan induksi atau orientasi dalam pelaksanaan TQM. Induksi tersebut ditujukan kepada guru/karyawan dalam meningkatkan kompetensi personil, sehingga tujuan peningkatan mutu dapat dicapai dengan maksimal.

b. Implementasi TQM yang diterapkan di MTs. Istiqomah Talamau merupkan langkah taktis strategis dalam meningkatkan mutu pendidikan. Maka, pelaksanaan TQM tersebut perlu dijadikan sebagai langkah utama dan perlu dipertahan untuk tetap dilaksanakan.

c. Dunia pendidikan harus menyadari bahwa TQM adalah solusi yang tepat 
dalam menyelesaikan persoalan pendidikan yang rumit sebagaimana yang kita lihat hari ini.

\section{KEPUSTAKAAN ACUAN}

Asmuni. (2013). Konsep Mutu dan Total Quality Management (TQM) dalam Dunia Pendidikan. Journal Ta'dib, Vol. 1, 16-42 (online): http://jurnal.radenfatah.ac.id/index.p $\mathrm{hp} /$ tadib/article/view/37 diunduh tanggal 21 September 2018 pukul 09.00

Asmuni. (2013). Konsep Mutudan Total Quality Management (TQM) dalam dunia pendidikan. Tesis Pasca Sarjana UIN Maulana Malik Ibrahim Malang, Indonesia.

Basrowi dan Suwandi. (2008). Memahami Penelitian Kualitatif. Jakarta: Rineka Cipta.

Hadis, Abdul dan Nurhayati B. (2014). Manajemen Mutu Pendidikan. Bandung: Alfabeta.

Himpunan Peraturan Perundang-undangan. (2006). Undang-undang Republik Indodesia Nomor 20 Tabun 2003 tentang Sistem Pendidikan Nasional (SISDIKNAS). Bandung: Fokusmedia.

Makbuloh, Deden. (2014).Manajemen Mutu Pendidikan Islam; Model Pengembangan Teori dan AplikasiSistim Penjaminan
Mutu. Jakarta: PT. Raja Grafindo Persada.

Nasution, M.N. (2005). Manajemen Mutu Terpadu. Jakarta: Ghalia Indonesia.

Nawawi, Hadari. (2005).Manajemen Sumber Daya Manusia Untuk Bisnis Yang Kompetitif. Yogyakarta: Gajah Mada Univercity Press.

Rasmi. (2014). Peningkatan Mutu dan Profil Lembaga Pendidikan dalam Perspektif Total Quality Management (TQM). Journal Al-Ta'dib, Vol. 7 (1), 54-67 (online): DOI http://dx.doi.org./10.31332/atdb.v7i 1.243 diunduh tanggal 21 September 2018 pukul 09.00

Rudi Prihantoro (2012), Konsep Pengendalian Mutu, Indonesia: Rosda.

Sugiyono, (2012), Memahami Penelitian Kualitatif, Bandung : Alfabeta.

Syukron B. (2017). Jurnal Pendidikan Ekonomi dan Bisnis. Implementasi Manajemen Mutu Terpadu Studi Transformasi pada Perguruan Tinggi, Vol. 5 (1), 51-62. Retrieved from (online):

http://doi.org/10.21009/JPEBDOI: doi.org/10.21009/JPEB.005.1.4. 2302-2663diunduh tanggal 20 September 2018 pukul 22.00

Tjiptono, Fandy dan Diana, Anastasia. (1998). Total Quality Manajemen. Yogyakarta: Andi Offset. 
Zahroh, Aminatul. (2014). Total Quality Management; Teori dan Praktik Manajemen untuk Mendongkrak Mutu Pendidikan. Malang: Ar-Ruzz Media.

Zahroh, Aminatul. (2015). Jurnal Cendekia. Total Quality Management: Capaian Kualitas Output melalui Sistem
Kontrol Mutu Sekolah, Vol. 9 (1): 7994. Retrieved from (online): http://dx.doi.org./1030957/cendekia .v9i1.54Web:

cendekia.pusatbahasa.or.id1978-2098;

2407-8557 diunduh tanggal 20

September 2018 pukul 22.00 